\title{
Atraumatic Endotracheal Tube for Mechanical Ventilation
}

\author{
Silvio Oscar Noguera Servin ${ }^{1}$, Gilson Barreto ${ }^{2}$, Luiz Cláudio Martins ${ }^{3}$, Marcos Mello Moreira ${ }^{4}$, \\ Luciana Meirelles ${ }^{5}$, José Alexandre Colli Neto ${ }^{6}$, José Hélio Zen Júnior ${ }^{6}$, Alfio José Tincani ${ }^{7}$
}

\begin{abstract}
Summary: Servin SON, Barreto G, Martins LC, Moreira MM, Meirelles L, Colli Neto JA, Zen Júnior JH, Tincani AJ - Atraumatic Endotracheal Tube for Mechanical Ventilation.

Background and objectives: Patients who need to stay under endotracheal intubation for long periods or when undergoing general anesthesia may develop tracheal lumen injuries due to pressure from distal cuff. In some cases, these injuries may evolve to stenosis or, occasionally, necrosis. The objective of this study was to present a modified endotracheal tube (METT) in which the cuff pressure is variable according to the cycle of mechanical ventilation (MV), which was tested on a lung simulator and animal model.
\end{abstract}

Methods: Two models of endotracheal tubes, a modified (METT) and a conventional (CETT), number $7.5 \mathrm{~mm}$ and $8.0 \mathrm{~mm}$, were connected to a lung simulator in a mechanical ventilator adjusted with two tidal volumes (TV) of 10 and $15 \mathrm{~mL}^{\mathrm{kg}} \mathrm{g}^{-1}$ and a compliance of $60 \mathrm{~mL}$.cmH $\mathrm{O}$ to evaluate the ventilatory efficiency of METT. Both models were also compared in Large-White pigs under general anesthesia and MV for 48 consecutive hours. Subsequently, animals were sacrificed for histopathological analysis of their tracheas.

Results: Both METTs (\#7.5 and 8.0) presented air leaks in lung simulator. The smallest air leak (13\%) was observed in METT \#7.5 with

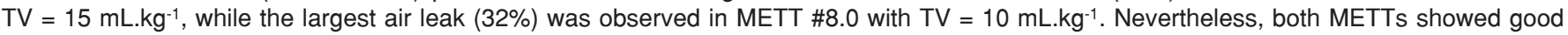
efficiency on the lung simulator. In animals, on histopathological analysis of their tracheas, it was found that METT caused less trauma to the epithelium when compared to CETT.

Conclusion: The use of a new model of ETT may decrease the risks of tracheal injury without hindering respiratory mechanics.

Keywords: Intubation, Intratracheal; Disposable equipament; Technology Assessment, Biomedical; Respiration, Artificial; Swine.

[Rev Bras Anestesiol 2011;61(3): 311-319] @Elsevier Editora Ltda.

\section{INTRODUCTION}

Endotracheal tube (ETT) is used quite often in the medical field in patients requiring mechanical ventilation (MV). This might be for a short period for example in general anesthesia, or more prolonged periods such as in patients who need MV in intensive care units (ICU).

The endotracheal tube has a distal cuff, whose function is to seal and protect the airways, therefore preventing aspiration of secretions and allowing positive pressure ventilation. The

Received from Universidade Estadual de Campinas (Unicamp) and Faculdade de Ciências Médicas, Brazil.

1. Master's Degree in Surgery Cirurgia, Post-graduate Student at the Departamento de Cirurgia of Faculdade de Ciências Médicas da Unicamp.

2. Head and Neck Surgeon of Hospital Centro Médico de Campinas; Chief of Oncologia Prefeitura de Paulínia

3. Assisting Physician of the Departamento de Clínica Médica, Faculdade de Ciências Médicas da Unicamp

4. Physiotherapist; Serviço de Doenças Pulmonares Unicamp

5. Professor, Physician of the Departamento de Anatomia Patológica of Faculdade de Ciências Médicas da Unicamp

6. Medical Student at Faculdade de Ciências Médicas da Unicamp

7. Associate Professor of the Departamento de Cirurgia of Disciplina de Cirurgia de Cabeça

e Pescoço of Faculdade de Ciências Médicas da Unicamp

Submitted on October 3, 2010.

Approved on December 7, 2010.

Correspondence to:

Dr. Alfio José Tincani

Departamento de Cirurgia Faculdade de Ciências Médicas

Cidade Universitária "Zeferino Vaz", $s / n^{\circ}$

Barão Geraldo

13083970 - Campinas, SP, Brazil

E-mail: alfio.jt@gmail.com distal cuff exerts a certain amount of pressure on the tracheal wall, which should not be elevated. If this happens, it could prevent blood flow to the tracheal mucosa. High-compliance and low-pressure cuffs may minimize the risk of mucosal ischemia, preventing injury. Therefore, the cuff inflation pressures should be adjusted between 20 and $30 \mathrm{cmH}_{2} \mathrm{O}$.

The most common endotracheal complications caused by the ETT cuff include laryngitis, glottic edema, mucosal ulceration, laryngeal stenosis, tracheal stenosis or dilation, inadvertent esophageal intubation, and innominate artery fistula 2,3 .

Tracheal ischemia may occur when the tracheal cuff is inflated with high pressures or when large ETTs are used for long periods. This may cause an inflammatory reaction and, often, tracheal stenosis. The studies of Cooper \& Grillo ${ }^{4}$ indicated that the pressure applied by the cuff on tracheal wall represents the main factor of tracheal stenosis. This complication varies between $1.5 \%$ and $19.5 \%$. Other studies demonstrated that patients may develop laryngeal stenosis when intubated for short periods between 24 and 48 hours ${ }^{3,5,6}$, more often affecting the glottis at the level of cricoid cartilage ${ }^{5,7}$.

The pressure inside the cuff is the most important factor in the genesis of post-intubation tracheal injury 4,8 . In an attempt to decrease the effects of cuff's pressure on the tracheal epithelium, Kamen \& Wilkinson ${ }^{9}$ recommended a cuffed tube filled with foam. More than three decades ago, Arola \& Anttinen ${ }^{9}$ in an experimental study with tubes with double cuffs inflated alternately reported pressures ranging from 63.8 to $74.3 \mathrm{mmHg}$. They stopped using this type of tube when they observed injuries in both contact points. 
12. Lindholm CE - Experience with a new orotracheal tube. Acta Otolaryngol (Stockh), 1973;75:389-390.

13. Nordin $U$, Lindholm CE, Wolgast $M$ - Blood flow in the rabbit tracheal mucosa under normal conditions and under the influence of tracheal intubation. Acta Anaesthesiol Scand, 1977;21:81-94.

14. Moro ET - Prevenção da aspiração pulmonar do conteúdo gástrico.. Rev Bras Anestesiol, 2004;54:261-275.

15. American Association for Respiratory Care - AARC (American Association for Respiratory Care) clinical practice guideline. Management of airway emergencies. Respir Care, 1995;40:749-760.

16. Brichet A, Verkindre C, Dupont J et al. - Multidisciplinary approach to management of postintubation tracheal stenoses. Eur Respir J, 1999;13:888-893.

17. Lindholm CE - Prolonged endotracheal intubation. Acta Anaesthesiol Scand, 1970;( Suppl 33):1-131.

18. Klainer AS, Turndorf $\mathrm{H}, \mathrm{Wu} W \mathrm{WH}$ et al. - Surface alterations due to endotracheal intubation. Am J Med, 1975;58:674-683.

19. Paegle RD, Ayres SM, Davis S - Rapid tracheal injury by cuffed airways and healing with loss of ciliated epithelium. Arch Surg, 1973;106:31-34.

20. Bryant LR, Trinkle JK, Dubilier L - Reappraisal of tracheal injury from cuffed tracheostomy tubes. Experiments in dogs. JAMA, 1971;215:625-628.

21. Valles J, Artigas A, Rello J et al. - Continuous aspiration of subglottic secretions in preventing ventilator-associated pneumonia. Ann Intern Med, 1995;122:179-186.

Resumen: Servin SON, Barreto G, Martins LC, Moreira MM, Meirelles L, Colli Neto JA, Zen Júnior JH, Tincani AJ - Fijación Atraumática de Tubo Endotraqueal para Ventilación Mecánica.

Justificativa y objetivos: Pacientes que necesitan permanecer bajo intubación endotraqueal (IOT), durante largos períodos o que tienen que ser sometidos a la anestesia general, podrán tener lesiones en la luz de la tráquea debido a presiones ejercidas por el balón terminal. En algunos casos, esas lesiones podrán evolucionar para una estenosis o a veces necrosis. El presente trabajo quiso presentar un tubo endotraqueal modificado (TETM), en que la presión del balón varía de acuerdo con el ciclo de la ventilación mecánica (VM), siendo el mismo testado en un simulador pulmonar y modelo animal.

01. Sole ML, Penoyer DA, Su X et al. - Assessment of endotracheal cuff pressure by continuous monitoring: a pilot study. Am J Crit Care, 2009;18:133-143.

02. Bain JA - Late complications of tracheostomy and prolonged endotracheal intubation. Int Anesthesiol Clin, 1972;10:225-244.

03. Tornvall SS, Jackson KH, Oyanedel E - Tracheal rupture, complication of cuffed endotracheal tube. Chest, 1971;59:237-239.

04. Cooper JD, Grillo HC - Experimental production and prevention of injury due to cuffed tracheal tubes. Surg Gynecol Obstet, 1969;129:12351241.

05. Bishop MJ - Mechanisms of laryngotracheal injury following prolonged tracheal intubation. Chest, 1989;96:185-186.

06. Yang KL - Tracheal stenosis after a brief intubation. Anesth Analg, 1995;80:625-627.

07. McCulloch TM, Bishop MJ - Complications of translaryngeal intubation. Clin Chest Med, 1991;12:507-521.

08. Magovern GJ, Shively JG, Fecht D et al. - The clinical and experimental evaluation of a controlled-pressure intratracheal cuff. J Thorac Cardiovasc Surg, 1972;64:747-756.

09. Kamen JM, Wilkinson CJ - A new low-pressure cuff for endotracheal tubes. Anesthesiology, 1971;34:482-485.

10. Arola MK, Anttinen J - Post-mortem findings of tracheal injury after cuffed intubation and tracheostomy. A clinical and histopathological study. Acta Anaesthesiol Scand, 1979;23:57-68.

11. Conti M, Pougeoise M, Wurtz A et al. - Management of postintubation tracheobronchial ruptures. Chest, 2006;130:412-418. co y ajustado con dos volúmenes corrientes (VC) de 10 y $15 \mathrm{~mL} . \mathrm{kg}^{-1}$ y complacencia de $60 \mathrm{~mL} . \mathrm{cmH}_{2} \mathrm{O}^{-1}$, fueron utilizados dos modelos de tubos endotraqueales: uno modificado (TETM), y el otro convencional (TETC), números (\#) 7,5 mm y $8,0 \mathrm{~mm}$, para evaluar la eficiencia de la ventilación con el TETM. También se hizo la comparación entre los dos modelos, en cerdos de la raza Large-White, bajo anestesia general y VM por 48 horas consecutivas. Posteriormente, los animales se sacrificaron para el análisis histopatológico de las tráqueas.

Resultados: Los dos TETMs ( $\# 7,5$ y 8,0) presentaron un escape de aire en el simulador pulmonar. El menor de los escapes de aire (13\%), fue visto en el TETM \#7,5 mm, con VC $=15 \mathrm{~mL} . \mathrm{kg}^{-1}$, y el mayor (32\%) en el TETM \#8,0 mm, con VC $=10 \mathrm{~mL} \cdot \mathrm{kg}^{-1}$. A pesar de eso, los dos TETMs presentaron una buena eficacia en el simulador pulmonar. En la evaluación del uso de los TETs en animales, analizando la histopatología de sus tráqueas, verificamos que el TETM causó menos áreas traumáticas en su epitelio en comparación con el TETC.

Conclusiones: El uso de un nuevo modelo de TET podrá disminuir los riesgos de lesión traqueal sin prejudicar la mecánica respiratoria.

Descriptores: ANIMAL: cerdo; AVALIACIÓN; COMPLICACIONES: intubación traqueal; EQUIPOS: tubo traqueal; REANIMACIÓN.
Método: En un simulador pulmonar acoplado a un ventilador mecáni- 
In an experimental study with rabbits, the authors evaluated tracheal blood flow. They demonstrated that tracheal mucosal ischemia is seen when the cuff pressure exceeds $30 \mathrm{mmHg}{ }^{11,12}$. In another study also with rabbits Nordin et al. ${ }^{13}$ demonstrated that a cuff pressure above $40 \mathrm{cmH}_{2} \mathrm{O}$ causes mucosal ischemia and recommended that this pressure should be below $26 \mathrm{cmH}_{2} \mathrm{O}$.

To attenuate adverse effects caused by cuff pressure on tracheal mucosa during tracheal intubation a modified ETT (METT) was developed and patented, both nationally and internationally (Patent deposit \# INPI: 11/08/2007. Patent number MU8702392-0U2, Classification A61M39/10). The main goal of the METT is to allow variation in the cuff internal pressure during respiratory cycles, according to MV.

Respiratory mechanics and occasional deleterious effects on the trachea were evaluated in a lung simulator (test lung). To demonstrate possible tracheal mucosal injuries, an animal model was ventilated mechanically with the conventional ETT (CETT) and compared to the METT.

\section{METHODS}

The new ETT model shows variation in the distal cuff pressure according to cycle of MV. The ETT model has three identical perforations within its distal cuff, of $3 \mathrm{~mm}$ each, to allow the cuff inflation during the inspiratory cycle and deflation in the expiratory phase. The tube also allows the use of an external tube to aspirate secretions that accumulates around the cuff.

An experimental study and a pilot study were performed to determine air leaks and tracheal injuries that the METT and CETT could cause, respectively.

A DX $3010^{\circledR}$ Dixtal mechanical ventilator was used cycled by volume with a tidal volume of 10 and $15 \mathrm{~mL} . \mathrm{kg}^{-1}$ and positive end-expiratory pressure (PEEP) of zero and $5 \mathrm{cmH}_{2} \mathrm{O}$, respectively, with a respiratory rate of 12 cycles per minute, and an inspiratory/expiratory ratio of 1:2,.

The lung simulation equipment used was the $\mathrm{Vent} \mathrm{Aid}^{\circledR}$ TLL ${ }^{\text {TM }}$ Training/Test Lung (Michigan Instruments Incorporation, Michigan, $\mathrm{MC}$ ). The adjusted compliance used in this simulator was $60 \mathrm{~mL} . \mathrm{cmH}_{2} \mathrm{O}^{-1}$.

Endotracheal tubes \#7.5 and $8.0 \mathrm{~mm}$ were used. The pressure on the CETT cuff was adjusted for $25 \mathrm{cmH}_{2} \mathrm{O}$, which differed from the METT, in which it varied during the respiratory cycle. A flow sensor of the respiratory profile monitor CO²MO PLUS DX-8100 (Dixtal/Novametrix, São Paulo, Brazil) was connected to both ETTs (placed between the mechanical ventilator and the pulmonary simulator). Air leakage was calculated by the difference between the inspiratory $(\mathrm{Vi})$ and expiratory $(\mathrm{Ve})$ volumes. Data regarding respiratory mechanics were stored continuously on a computer, for three minutes, by the software Analysis Plus ${ }^{\circledR}$. At the end of this period, data were processed and analyzed.

An experimental pilot study was performed to compare both ETTs and the occasional occurrence of lesions. The same endotracheal tubes (METT and CETT, \#7.5 mm) were used in two Large-White pigs with similar weights of $35 \mathrm{~kg}$. The same mechanical ventilator of the first study was used cycled by volume $\left(15 \mathrm{~mL} \mathrm{~kg}^{-1}\right)$, respiratory rate of 12 cycles per minute, PEEP $=0 \mathrm{cmH}_{2} \mathrm{O}, \mathrm{FiO}_{2}=0.21 \%$. CETT cuff pressure was set to $25 \mathrm{cmH}_{2} \mathrm{O}$. Both animals remained anesthetized and on mechanical ventilation for 48 hours. Afterwards, the animals were sacrificed and both tracheas were analyzed for possible macroscopic and histological injuries.

\section{RESULTS}

Table I shows the mean values obtained in the first experiment with the \# $7.5 \mathrm{~mm}$ CETT and METT. Greater air leaking (23\%) was observed in METT with TV of $10 \mathrm{~mL}^{\mathrm{kg}}{ }^{-1}$ and PEEP of $0 \mathrm{cmH}_{2} \mathrm{O}$, and lower air leaking (13\%) with TV of $15 \mathrm{~mL} \cdot \mathrm{kg}^{-1}$ and PEEP of $5 \mathrm{cmH}_{2} \mathrm{O}$.

There was less air leakage in CETT (3\% and 6\%).

The greater inspiratory pressure of METT cuff was $10.5 \mathrm{cmH}_{2} \mathrm{O}$, while the CETT cuff pressure was constant at $25 \mathrm{cmH}_{2} \mathrm{O}$.

Table II shows the mean values obtained with the \#8 $\mathrm{mm}$ CETT and METT in which the greater air leaking (32\%) was observed with TV of $10 \mathrm{~mL} \cdot \mathrm{kg}^{-1}$ and PEEP of $5 \mathrm{cmH}_{2} \mathrm{O}$. The lower air leaking (20\%) was observed with TV of $15 \mathrm{~mL} . \mathrm{kg}^{-1}$ and PEEP of $0 \mathrm{cmH}_{2} \mathrm{O}$.

The air leakage observed with the CETT was $8 \%$ and $13 \%$.

The greater inspiratory pressure in METT cuff was $10 \mathrm{cmH}_{2} \mathrm{O}$, while the pressure in CETT cuff was constant, at $25 \mathrm{cmH}_{2} \mathrm{O}$.

Table I - Mean Values Obtained with Both \#7.5 mm Endotracheal Tubes

\begin{tabular}{|c|c|c|c|c|c|c|c|}
\hline & & METT & & & CETT & & \\
\hline Tidal volume & PEEP & $\mathrm{Vi} / \mathrm{Ve}$ & $\begin{array}{l}\% \\
\text { leak }\end{array}$ & $\begin{array}{l}\text { Cuff pressure } \\
\text { (insp/exp) }\end{array}$ & $\mathrm{Vi} / \mathrm{Ve}$ & $\begin{array}{l}\% \\
\text { leak }\end{array}$ & $\begin{array}{l}\text { Cuff } \\
\text { pressure }\end{array}$ \\
\hline 15 mL.kg ${ }^{-1}$ & 0 & $960 / 814$ & $15 \%$ & $7.5 / 0$ & 1014 / 984 & $3 \%$ & 25 \\
\hline 10 mL.kg ${ }^{-1}$ & 5 & $659 / 514$ & $22 \%$ & $8 / 3$ & 692 / 651 & $6 \%$ & 25 \\
\hline 15 mL.kg ${ }^{-1}$ & 5 & 962 / 835 & $13 \%$ & $10.5 / 3.5$ & $1015 / 975$ & $4 \%$ & 25 \\
\hline
\end{tabular}

CETT: conventional endotracheal tube; METT: modified endotracheal tube; PEEP: positive end-expiratory pressure (cm $\mathrm{H}_{2} \mathrm{O}$ ); Vi/Ve: inspiratory and expiratory volumes $(\mathrm{mL})$; \% leak: difference between inspiratory and expiratory volumes $(\mathrm{mL})$; cuff pressure $\left(\mathrm{cmH}_{2} \mathrm{O}\right)$ during the expiratory and inspiratory phases. 
Table II - Mean Values of Both \# 8 mm Endotracheal Tubes (CETT and METT)

\begin{tabular}{|c|c|c|c|c|c|c|c|}
\hline & & METT & & & CETT & & \\
\hline 15 mL.kg ${ }^{-1}$ & 0 & $966 / 769$ & $20 \%$ & $6 / 0$ & $1020 / 941$ & $8 \%$ & 25 \\
\hline $10 \mathrm{~mL} \cdot \mathrm{kg}^{-1}$ & 5 & $660 / 451$ & $32 \%$ & $7 / 2$ & 698 / 609 & $13 \%$ & 25 \\
\hline $15 \mathrm{~mL} . \mathrm{kg}^{-1}$ & 5 & $964 / 749$ & $22 \%$ & $10 / 3$ & 1024 / 923 & $10 \%$ & 25 \\
\hline
\end{tabular}

CETT: conventional endotracheal tube; METT: modified endotracheal tube; PEEP: positive end-expiratory pressure (cmH $\mathrm{H}_{2} \mathrm{O}$ ); Vi/Ve: inspiratory and expiratory volumes $(\mathrm{mL})$; \% leak: difference between inspiratory and expiratory volumes $(\mathrm{mL})$; cuff pressure $\left(\mathrm{cmH}_{2} \mathrm{O}\right)$ during the expiratory and inspiratory phases.

In the pilot study, the animal using METT showed macroscopically less severe tracheal lesions without visible lesions (Figure 1, arrow), while the animal using CETT showed areas of necrosis and ulcerations (Figure 2, arrow).

Microscopically, the animal using METT showed areas with preserved respiratory epithelium (Figure 3, arrow). On

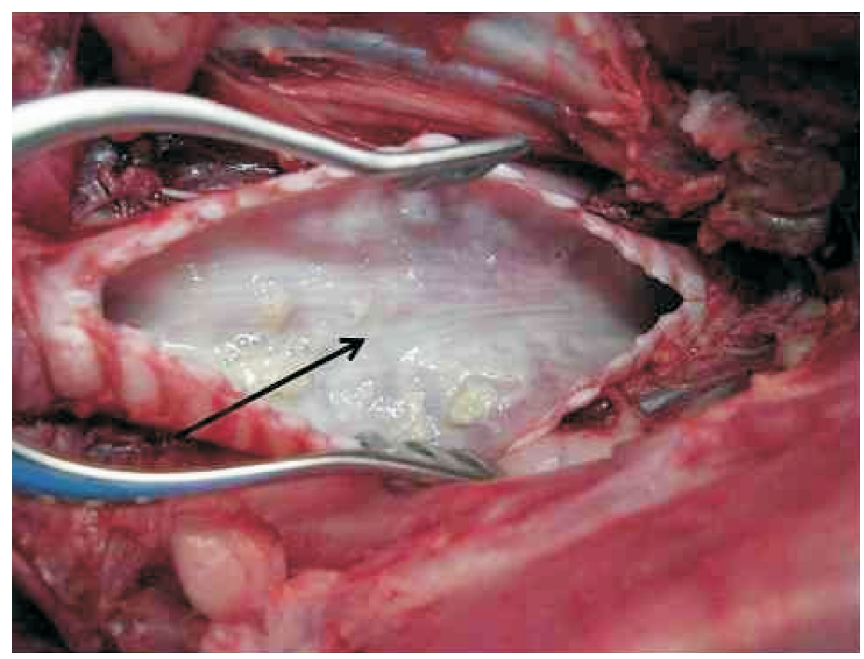

Figure 1 - Animal Trachea Opened Longitudinally. The animal remained with the Modified Endotracheal Tube METT) for 48 Consecutive Hours. Note the Preservation of the Epithelium (arrow).

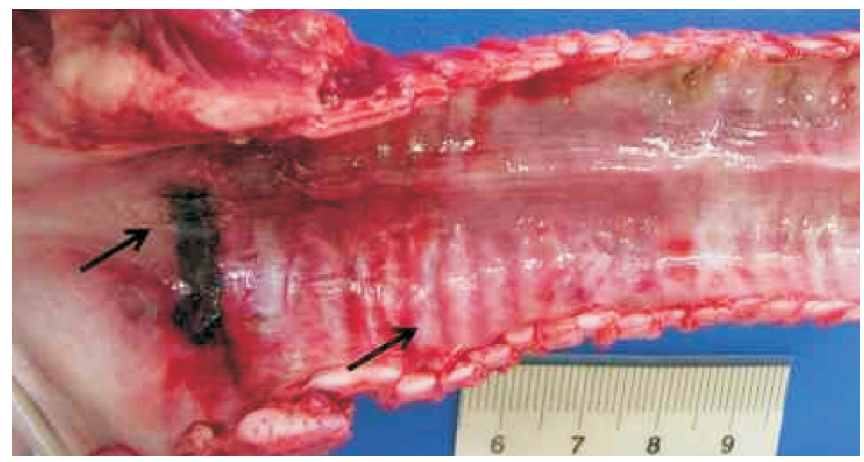

Figure 2 - The Arrows Demonstrate on the Trachea, Opened Longitudinally, Damage to the Epithelium. Those are Greater on a Lower Segment, Indicated by the Ruler. This Animal Remained with the Conventional Endotracheal Tube (CETT) for 48 Consecutive Hours.

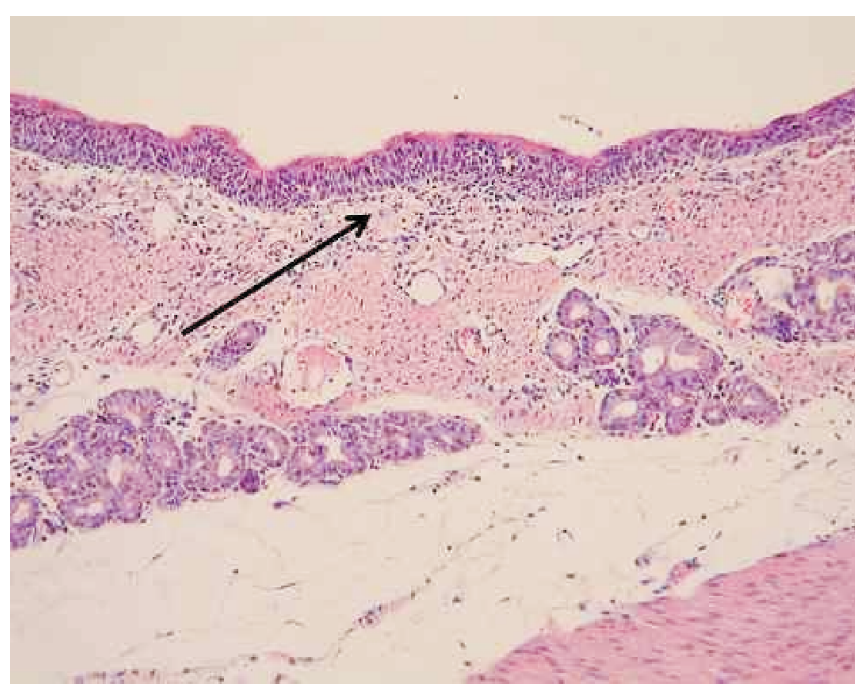

Figure 3 - Microscopic Tracheal Examination of the Animal that Remained with the METT for 48 Consecutive Hours. The Arrow Shows the Epithelium with Mild inflammatory Process and Preserved Mucosa (H\&E - 400X).

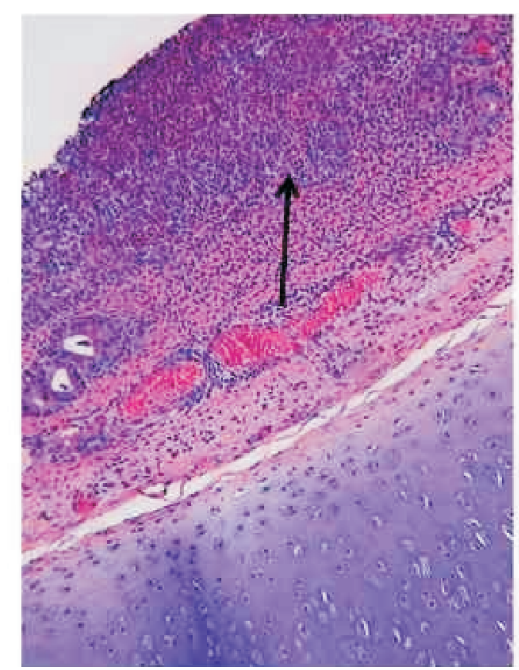

Figure 4 - Microscopic Tracheal Examination of the Animal with the CETT. The Arrow Shows the Epithelium with Intense Linflammatory Process, Ulcerated Areas and Erosions. The Inflammatory Process reaches up to the Perichondrium. (H\&E - 400X). 
histological evaluation the animal using CETT had an intense inflammatory process with ulcerated areas and erosions on tracheal epithelium (Figure 4, arrow). Extensive areas of deepithelization and foci of associated hemorrhage were also observed. In ulcerated areas neutrophilic perichondritis and acute inflammation extending up to the adventitia was observed, contrary to what happened to the animal using METT.

\section{DISCUSSION}

When compared with CETT, the METT showed in the first experiment lower cuff pressure. This did not depend on the phase of the respiratory cycle or larger tidal volumes and PEEP used. On the other hand, \# $8 \mathrm{~mm}$ METT showed greater air leaking (32\% higher than the CETT). In the pilot study, we observed that METT was associated with less tracheal injury, both macro- and microscopically.

Compared with CETT, the METT is composed of an identical endotracheal tube used for intubation. In order to have cycles during MV, the tube inside the cuff has millimetric holes. These holes cause the passage and exit of air during MV (both on inspiration and expiration). Since it is not constantly insufflated the contact with tracheal mucosa is smaller and, consequently, possible mucosal injuries are practicably negligible. This comparative demonstration was possible in the pilot study with animals.

In general, the objective of ETTs is to allow the passage of air. The inflated cuff protects the airways from aspirating secretions, closing the trachea and allowing effective alveolar ventilation. Aspiration of gastric contents is not common during anesthesia, but it requires preventive measures such as the use of drugs that reduce its volume and acidity. However, tracheal intubation is the best method to prevent gastric aspiration in these situations ${ }^{14}$. The cuff, when in contact with the mucosa, will cause endotracheal injury due to the pressure exerted. Current cuffs close the trachea through a greater area of contact with the mucosa. This allows a lower pressure inside, reflecting on the mucosa minimizing the incidence of ischemia, and consequently fewer injuries. This less deleterious effect of the low pressure tubes will not be seen if a smaller diameter than necessary is used. In tubes of lower caliber, cuffs will require larger volumes to achieve adequate closure, causing an increase in pressure and ischemic changes, which lead to complications especially if longer periods of intubation are required.

The most feared complications of tracheal intubation for longer periods continue to attract considerable attention in the literature. Among the most common, we could mention subglottic laryngeal and tracheal stenosis $11,15,16$.

Lindholm ${ }^{17}$ investigated 35 cases of prolonged intubation with rubber, latex, and PVC tubes. In all cases, he observed damage in the area of contact with the cuff, with different degrees of inflammation and/or necrosis. Klainer et al. ${ }^{18}$ demonstrated the presence of tracheal damage in the area of the low-pressure cuff after two hours of intubation, which was demonstrated through electron microscopy. Ciliary disorganization with loss of the histological pattern was observed in some areas.

Magovern et al. ${ }^{8}$ developed a cuff with an external pressure regulator system. When excessive volumes of air are injected inside the cuff, another external cuff of an extremely elastic material distends. This will avoid an increase in pressure above $30 \mathrm{cmH}_{2} \mathrm{O}$ in the internal cuff. This system has some drawbacks, such as the price (approximately 10 times more than the conventional tube) and it can frequently show rupture of the system.

In another extreme, Peagle et al. ${ }^{19}$ investigated 54 patients in whom two models of PVC tube with latex cuff (red tube) were used and who died and underwent autopsy. Pressures were not systematically controlled, but they were between 150 and $300 \mathrm{mmHg}$. The histological study of the tracheas showed loss of ciliary epithelium with less than 12 hours of intubation. The inflammatory reaction extended to the margins of cartilage with signs of early necrosis.

Therefore, the METT represents an alternative to the situation presented and indicated by the pilot study presented here, since it causes little damage to the tracheal mucosa, as observed in the studied animal.

In the first phase of the study, the METT showed greater air leaking than the CETT. In an attempt to minimize this situation, a PEEP of $5 \mathrm{cmH}_{2} \mathrm{O}$ was used. This measure was not effective in reducing the percentage of air leaking (Tables I and II).

Note that with the smaller diameter METT (\# $7.5 \mathrm{~mm}$ ) the percentage of air leaking was also smaller. The smaller diameter cuff of METT has a greater volume capacity when compared to the METT of greater diameter during the inspiratory phase, which could explain this reduction in air leaking. This will result in delayed emptying during the expiratory phase, therefore allowing better seal and less air leaking.

Bryant et al. ${ }^{20}$ concluded, in their findings on ETT-related damage, that temporarily emptying the cuff or changing its position was not enough to prevent tracheal mucosa necrosis and/or cartilage damage.

An ETT with a pressure regulating valve of distal cuff is available on the market. This decreases tracheal trauma; however, the damages remain and its cost is very high ${ }^{21}$.

With METT, less tracheal damage was observed without significant impairment of air leaking. The price, when produced in large scale, will not differ from the current price of CETTs. Further experimental and clinical studies are necessary to determine possible limitations of this method, which demonstrated to reduce the risk of tracheal damage without causing relevant harm to respiratory mechanics. 
12. Lindholm CE - Experience with a new orotracheal tube. Acta Otolaryngol (Stockh), 1973;75:389-390.

13. Nordin $U$, Lindholm CE, Wolgast $M$ - Blood flow in the rabbit tracheal mucosa under normal conditions and under the influence of tracheal intubation. Acta Anaesthesiol Scand, 1977;21:81-94.

14. Moro ET - Prevenção da aspiração pulmonar do conteúdo gástrico.. Rev Bras Anestesiol, 2004;54:261-275.

15. American Association for Respiratory Care - AARC (American Association for Respiratory Care) clinical practice guideline. Management of airway emergencies. Respir Care, 1995;40:749-760.

16. Brichet A, Verkindre C, Dupont J et al. - Multidisciplinary approach to management of postintubation tracheal stenoses. Eur Respir J, 1999;13:888-893.

17. Lindholm CE - Prolonged endotracheal intubation. Acta Anaesthesiol Scand, 1970;( Suppl 33):1-131.

18. Klainer AS, Turndorf $\mathrm{H}, \mathrm{Wu} W \mathrm{WH}$ et al. - Surface alterations due to endotracheal intubation. Am J Med, 1975;58:674-683.

19. Paegle RD, Ayres SM, Davis S - Rapid tracheal injury by cuffed airways and healing with loss of ciliated epithelium. Arch Surg, 1973;106:31-34.

20. Bryant LR, Trinkle JK, Dubilier L - Reappraisal of tracheal injury from cuffed tracheostomy tubes. Experiments in dogs. JAMA, 1971;215:625-628.

21. Valles J, Artigas A, Rello J et al. - Continuous aspiration of subglottic secretions in preventing ventilator-associated pneumonia. Ann Intern Med, 1995;122:179-186.

Resumen: Servin SON, Barreto G, Martins LC, Moreira MM, Meirelles L, Colli Neto JA, Zen Júnior JH, Tincani AJ - Fijación Atraumática de Tubo Endotraqueal para Ventilación Mecánica.

Justificativa y objetivos: Pacientes que necesitan permanecer bajo intubación endotraqueal (IOT), durante largos períodos o que tienen que ser sometidos a la anestesia general, podrán tener lesiones en la luz de la tráquea debido a presiones ejercidas por el balón terminal. En algunos casos, esas lesiones podrán evolucionar para una estenosis o a veces necrosis. El presente trabajo quiso presentar un tubo endotraqueal modificado (TETM), en que la presión del balón varía de acuerdo con el ciclo de la ventilación mecánica (VM), siendo el mismo testado en un simulador pulmonar y modelo animal.

01. Sole ML, Penoyer DA, Su X et al. - Assessment of endotracheal cuff pressure by continuous monitoring: a pilot study. Am J Crit Care, 2009;18:133-143.

02. Bain JA - Late complications of tracheostomy and prolonged endotracheal intubation. Int Anesthesiol Clin, 1972;10:225-244.

03. Tornvall SS, Jackson KH, Oyanedel E - Tracheal rupture, complication of cuffed endotracheal tube. Chest, 1971;59:237-239.

04. Cooper JD, Grillo HC - Experimental production and prevention of injury due to cuffed tracheal tubes. Surg Gynecol Obstet, 1969;129:12351241.

05. Bishop MJ - Mechanisms of laryngotracheal injury following prolonged tracheal intubation. Chest, 1989;96:185-186.

06. Yang KL - Tracheal stenosis after a brief intubation. Anesth Analg, 1995;80:625-627.

07. McCulloch TM, Bishop MJ - Complications of translaryngeal intubation. Clin Chest Med, 1991;12:507-521.

08. Magovern GJ, Shively JG, Fecht D et al. - The clinical and experimental evaluation of a controlled-pressure intratracheal cuff. J Thorac Cardiovasc Surg, 1972;64:747-756.

09. Kamen JM, Wilkinson CJ - A new low-pressure cuff for endotracheal tubes. Anesthesiology, 1971;34:482-485.

10. Arola MK, Anttinen J - Post-mortem findings of tracheal injury after cuffed intubation and tracheostomy. A clinical and histopathological study. Acta Anaesthesiol Scand, 1979;23:57-68.

11. Conti M, Pougeoise M, Wurtz A et al. - Management of postintubation tracheobronchial ruptures. Chest, 2006;130:412-418. co y ajustado con dos volúmenes corrientes (VC) de 10 y $15 \mathrm{~mL} . \mathrm{kg}^{-1}$ y complacencia de $60 \mathrm{~mL} . \mathrm{cmH}_{2} \mathrm{O}^{-1}$, fueron utilizados dos modelos de tubos endotraqueales: uno modificado (TETM), y el otro convencional (TETC), números (\#) 7,5 mm y $8,0 \mathrm{~mm}$, para evaluar la eficiencia de la ventilación con el TETM. También se hizo la comparación entre los dos modelos, en cerdos de la raza Large-White, bajo anestesia general y VM por 48 horas consecutivas. Posteriormente, los animales se sacrificaron para el análisis histopatológico de las tráqueas.

Resultados: Los dos TETMs ( $\# 7,5$ y 8,0) presentaron un escape de aire en el simulador pulmonar. El menor de los escapes de aire (13\%), fue visto en el TETM \#7,5 mm, con VC $=15 \mathrm{~mL} . \mathrm{kg}^{-1}$, y el mayor (32\%) en el TETM \#8,0 mm, con VC $=10 \mathrm{~mL} \cdot \mathrm{kg}^{-1}$. A pesar de eso, los dos TETMs presentaron una buena eficacia en el simulador pulmonar. En la evaluación del uso de los TETs en animales, analizando la histopatología de sus tráqueas, verificamos que el TETM causó menos áreas traumáticas en su epitelio en comparación con el TETC.

Conclusiones: El uso de un nuevo modelo de TET podrá disminuir los riesgos de lesión traqueal sin prejudicar la mecánica respiratoria.

Descriptores: ANIMAL: cerdo; AVALIACIÓN; COMPLICACIONES: intubación traqueal; EQUIPOS: tubo traqueal; REANIMACIÓN.
Método: En un simulador pulmonar acoplado a un ventilador mecáni- 